\title{
PREFACE
}

\section{Dear Reader}

We are proud to continue the UCL Journal of Law and Jurisprudence's tradition of contributing to legal scholarship in a broad range of legal areas. Starting in 2015, the UCLJLJ has published two issues per volume, the first of which is general in scope, while the second one deals with different issues connected to an Editorial Boarddefined theme. This is the first issue of 2017. The chosen theme for the second issue, to be published in October 2017, is that of 'Crisis and the Law'.

The UCLJLJ continues to be freely available online and remains true to its generalist foundation, publishing articles on various areas of law and jurisprudence. The past year has been an exciting one for the development of the journal. In pursuit of building on the success of past editorial teams, we have established a Faculty Advisory Board, enabling us to draw on the vast expertise of the UCL Faculty of Laws.

We are also pleased that the UCL Law Journal Blog, also edited and published by graduate (Masters and PhD) students of UCL Laws, continues to publish scholarly contributions from academics, researchers and practitioners; showcasing outstanding research from post-graduate students at UCL and elsewhere. The Blog's primary aim is to make a high-quality contribution to current debates on local and global issues of law and jurisprudence on a free and accessible platform that covers up-to-date events, developments, debates, cases, and more.

Against this backdrop, we are proud to present this year's first issue. It opens with an economic analysis on the civil liability rules applicable to credit rating agencies. Julius Sher Xern Yee evaluates the relevant reforms of the European Union from a Kaldor-Hicks efficiency perspective. He claims that the changes in the legal framework regarding the assignment of rights constitute a positive development and that the current legal framework is efficient. Maria-Thomais Epeoglou's article follows, also considering recent EU reforms. In particular, she assesses the changes in the insolvency regulatory framework in light of their objective. Although the reforms provide certain improvements, Epeoglou argues that certain fundamental shortcomings - and most significantly, the lack of substantive harmonisation remain. 
The issue then turns to matters of domestic law. Daisuke Ikuta undertakes an analysis of the scope of two cases concerning the abuse of separate corporate personality and limited liability by corporate groups: Chandler $v$ Cape PLC and Thompson v Renwick Group PLC. He argues that the legal principle recognised in those cases, integrated with existing features of company law, could aid in the prevention of corporate group abuse of the separate corporate personality and limited liability doctrines. A further shift in focus to jurisprudential matters is provided by the following piece. Norman Swazo engages with a question of fundamental importance in modern times: how to properly understand Islamic ideology and Islamic law. By staging an intellectual encounter between the scholarship of Tariq Ramadan and Ronald Dworkin, Swazo builds an interpretive conception of Islamic ideology to act as a counter to orthodox, dogmatic conceptions.

The final three contributions pertain to human rights and humanitarian law matters. Roberto Andrade contributes with a comparative analysis on electoral libel, between the domestic laws and international obligations of Ecuador and the United Kingdom. The author identifies the interests at stake, underlining the similarities between the compared domestic and regional jurisdictions, while also providing insightful analysis regarding the differences. Charalampos Stylogiannis deals with one of the most essential labour law institutions: the right to strike. Engaging in an analysis of the right to strike under the European Convention of Human Rights, the author presents a critical view on the extent of protection initially acknowledged by the European Court of Human Rights, and how the incorporation of International Labour Organization standards has helped to reduce some of the limitations of its case law. The author calls for the ECtHR to continue with its 'enhanced protection' of the right to strike. Lastly, Eduard Hovsepyan contributes an article on the legal implications of attacks against human shields, voluntary and otherwise, in armed conflict. The rules governing the use of human shields and the complex legal and policy issues associated with competing constructions of these are considered and applied to divergent types of human shields. He concludes that while the current framework is adequate in regulating the phenomenon of human shields and attacks against them, certain aspects thereof remain somewhat unclear and deserve further analysis.

The hard work of everyone who has contributed to making this issue come to fruition must be acknowledged. A huge thank you goes to the members of the 
Editorial Board, who have all devoted substantial time and energy to reviewing and editing the articles. We are also particularly grateful to Lauren Chaplin who copyedited the final product. Warm thanks are due to our Faculty Editor, Dr Daniela Simone. Further, the commitment and assistance of the Faculty Advisory Board's members is greatly appreciated. Our appreciation goes out to our long-standing sponsors, Blackstone Chambers and Slaughter and May, for their generous financial contribution to the Journal. Last but not least, this issue could not have taken shape without the unwavering financial, academic, and administrative support of the UCL Faculty of Laws, with a very special mention to Robyn Parker and Ellie Forward.

We hope that you enjoy reading this issue.

Luis Felipe Viveros Montoya \& Niko Pavlopoulos Academic Editors

\author{
Conor Crummey \\ Managing Editor
}

C [2017], The Author(s). This is an Open Access article distributed under the terms of the Creative Commons Attribution License (CC-BY) 4.0 https://creativecommons.org/licenses/by/4.0/, which permits unrestricted use, distribution, and reproduction in any medium, provided the original author and source are credited. 